\section{EVALUATION OF THE QUALITY OF TEACHING FROM THE PERSPECTIVE OF UNIVERSITY STUDENTS}

\begin{abstract}
The concept of quality in tertiary education is important not only for education providers but also for society as a whole which expects the education to have a high level of quality and wants to maintain its trust in the education system on the national and international level. The objective of this paper is therefore to identify variables that, from the perspective of university students, affect the quality of taught courses, and use the results to formulate recommendations that would improve the quality of teaching at universities. Primary data was obtained through a quantitative survey among students in the Master's programme at a selected public university involving 450 respondents. The results showed that the overall rating of a course is more strongly influenced by variables related to the course's outcome, content and concept than the rating of the teacher. The main value lies in the general overview of the variables influencing the perception of the quality of taught courses by students that is beneficial for teachers who are preparing a course and also for higher education institutions developing a methodology for evaluating the quality of teaching and teachers.
\end{abstract}

\section{KEYWORDS}

Course, quality, quantitative survey, tertiary education, university students

\section{HOW TO CITE}

Fajčíková A., Fejfarová M. (2019) 'Evaluation of the Quality of Teaching from the Perspective of University Students', Journal on Efficiency and Responsibility in Education and Science, vol. 12, no. 2, pp. 34-40. http://dx.doi.org/10.7160/eriesj.2019.120201

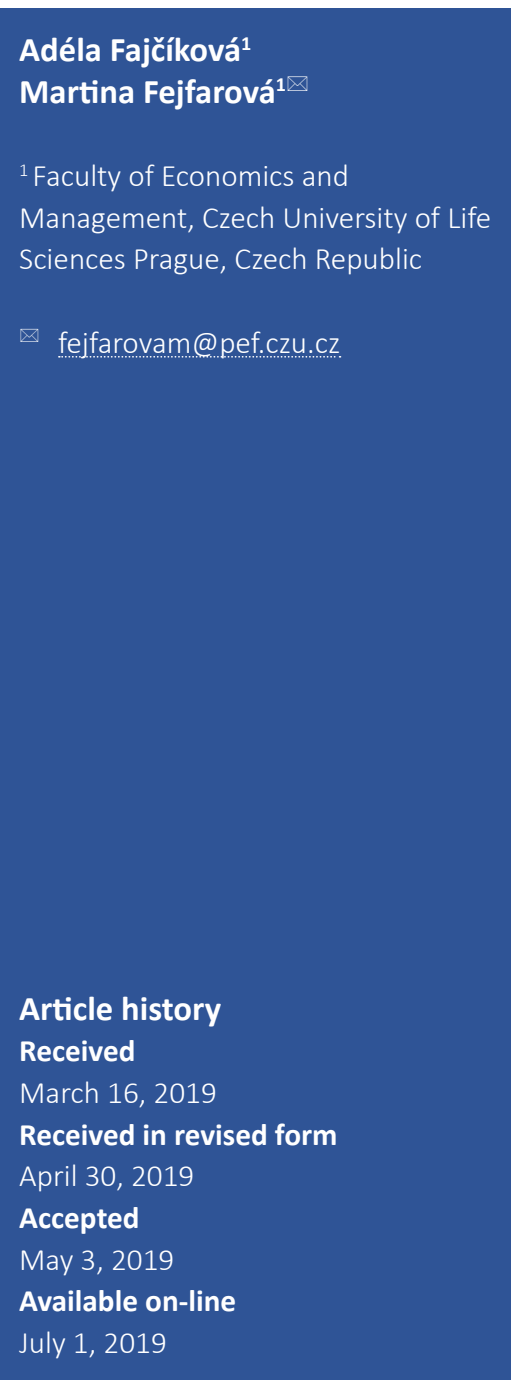

Highlights

- The evaluation of the quality of teaching from the perspective of university students via a quantitative approach.

- The general overview of the variables influencing the perception of the quality of taught courses by students.

- Students give positive ratings even to courses that are very difficult and require more self-study if they are considered beneficial.

- The overall rating of a course is more strongly influenced by variables related to the course's concept, content and outcome than the evaluation of the teacher.

\section{INTRODUCTION}

Higher education institutions as the highest level of the education system are leading centres of education, independent learning and creative activity, and play a crucial role in the scientific, cultural, social and economic development of society (Lesjak, 2018; Scott, Gallacher and Parry, 2017).

After years of preparations and negotiations, on 2 May 2016 a new amendment of the Act on Higher Education Institutions and on Amendments and Supplements to Some Other Acts (1998) became effective in the Czech Republic which, among other things, addresses internal evaluations of the quality of teaching, creative, and related activities of a higher education institution, consisting of a) the application of standards and methods of internal evaluation of the quality of teaching, creative, and related activities of a higher education institution; b) elaborating a report on internal evaluations of the higher education institution based on educational, creative, and related activities of the higher education institution describing attained qualitative outputs of the higher education institution together with measures accepted for removing potential deficiencies (to be published at intervals defined by the institution's internal regulations, but no less frequently than once in 5 years); and c) making the report and additions available for the bodies and members of bodies of a higher education institution and its parts as well as to the Accreditation Bureau and the Ministry of Education (Higher Education Institutions and on Amendments and Supplements to Some Other Acts, 1998). At the same time, the Government Regulation on Standards for Accreditation 
in Higher Education was published; this regulation became effective on 1 September 2016 and determines the standards for institutional accreditation, standards for accreditation of a degree programme, standards for accreditation of the habilitation procedure and standards for accreditation of the procedure for appointment of a professor. The standards for institutional accreditation among other requirements also include the existence of an internal quality assurance and assessment system of educational, creative, and activities related to the higher education institution. In educational, creative, and related activities, the higher education institution must have certain indicators set up that allow it to monitor a success rate at the admission procedure, drop-out rate in the degree programme, rate of completion of studies within a degree programme and rate of graduate employment (Government Regulation no. 274/2016 Coll.).

The fundamental roles of higher education institutions include education, scientific research and the 'third role' which covers a broad range of activities not included in either of the previous two traditional categories. Recent literature has also started talking about a 'fourth role' which according to Pawłowski (2009) contributes to the development of regions where the institutions are located. Unlike some economists who strictly insist on applying a cost-benefit analysis to tertiary education spending, Bowen (2018) claims that the non-monetary benefits of a tertiary education far outweigh the monetary component. According to a strategic document of the Ministry of Education, Youth and Sports (2015) titled Higher Education Development Framework for 2020, one of the greatest challenges of the upcoming period is a sharp decline in the number of students from the traditional population caused by demographic development. For this reason, it is necessary to constantly seek answers to the question how to efficiently secure and keep increasing the quality of all the activities of higher education institutions and how to increase the value and relevance of education for each student. According to Chui et al. (2016) and Ming (2010), the market of higher education institutions is highly competitive, unstable and turbulent. If a higher education institution is to weather all economic and social change, it needs to understand the needs of its students better to be able to attract and retain them (Wiese, Van Heerden and Jordaan, 2010). The issue of improving the quality of education is, therefore, a hotly discussed topic on all levels of society, as the quality of education has a major impact on students, teachers, the government and public as a whole (Leeuwenkamp, Brinke and Kester, 2017).

The issues of maintaining the quality of the education system are currently in the centre of attention and the subject of many specialised papers. The concept of quality in tertiary education is important not only for the institutions that provide education but also for society as a whole which expects the education to have a high level of quality and wants to maintain its trust in the education system on the national and international level (Prisacariu, 2015).

The quality of a higher education institution can be assessed either from the perspective of the quality of the teaching itself or by evaluating the results and knowledge of the students (Pereira, Araujo and Machado-Taylor, 2018), examining their progress in learning and skill development by comparing the situation before and after the educational activities (Ďurišová, Kucharčíková and Tokarčíková, 2015). This paper focuses on quality evaluation from the perspective of students whose expectations and needs are what each higher education institution should primarily strive to fulfil.

The quality of education is influenced by many factors. Devadoss and Foltz (1996) and Dolton, Marcenaro and Navarro (2003) analysed the relationship between student attendance and academic performance. The results of the research show that attendance at lectures, seminars etc. clearly brings numerous benefits to students (Stanca, 2006). Lindstadt (2005) and McCluskey, Bynum and Patchin (2004) agree that the critical factors that decide on whether students take part in the learning process or not include among individual, family or social aspects also factors related to the tertiary education institution as such - its structure, rules, environment or employees. Because teachers are the main bearers of knowledge in a higher education institution, they are also among the main factors influencing the institution's quality (El-Hilali, Al-Jaber and Hussein, 2015). For this reason, it is important to regularly evaluate the efficiency of teachers and identify their strengths and weaknesses which may help improve their personal performance but also play an important role for the institution itself when drafting its policy for hiring teachers and conducting their professional development (Medallon and Martinez, 2014). Adnot et al. (2017) and Stronge (2018) claim that teachers have a strong and lasting impact on students, influencing not just what the students learn but also how and how often, what is their attitude towards their studies and the institution and how they influence and are influenced by their environment. According to Medallon and Martinez (2014), teachers are typically evaluated in four dimensions: personal characteristics, professional competence, classroom management and the teacher-student relationship. Stronge (2018) emphasises beside the teacher's professional knowledge and skills also the ability to plan the teaching, to teach the course content, objectively assess, create a positive atmosphere and act professionally.

Hoang et al. (2016) claim that the existence and sustainable growth of any organisation depends on customer satisfaction. It can be said, therefore, that the objective of any higher education institution that wishes to succeed in the competitive environment is to provide a high quality of services, improve student engagement and seek ways how to fulfil the needs and wishes of its students better than other institutions (Orindaru, 2015).

The objective of this paper is therefore to identify variables that, from the perspective of university students, affect the quality of taught courses, and use the results to formulate recommendations that would improve the quality of teaching at universities.

We formulated the following research questions:

- Is there a significant dependency relationship the overall rating of a course and the variables such as age, gender, study programme or other identification variables?

- Is the rating of a course significantly influenced by regular attendance of the student at the lectures? 
- What variables have the most significant impact on the perceived quality of teaching from the perspective of university students?

- Is the overall rating of the course primarily influenced by variables relating to the course itself, the method of teaching the course or the personality of the teacher?

The paper is structured as follows: First, the summary of the current knowledge is presented in Introduction. The section Materials and Methods describes the used research methods and statistical techniques in this paper. The gathered findings are assessed in Results. The achieved and presented results are then elaborated and compared with those of international studies in Discussion. This part also contains subsequent recommendations for teachers who are preparing the educational courses, teachers who are interested in improving the students' interest in existing courses and for higher education institutions and identifies the benefits and limitations of the paper. The section Conclusion summarises the main findings.

\section{MATERIALS AND METHODS}

Primary data was obtained in a quantitative survey involving 450 respondents. The participants were purposefully selected: the questionnaire respondents were the students of the two largest Master's programmes at the Faculty of Economics and Management, Czech University of Life Sciences Prague (FEM CULS Prague): Economics and Management (EM) and Business Administration (BA). The questionnaire only targeted students in the fourth and fifth year of the fulltime study programme in Czech. The research was carried out in the academic years 2016/2017 and 2017/2018; the students were asked about characteristics that influence their perception of 11 taught courses. In the survey, we asked 9 questions consisting of 6 identification questions and 3 summary research questions which comprised individual claims concerning the assessment of the course, teaching and teacher. In the identification questions, the respondents could choose one answer; in research questions, they indicated their agreement with individual claims using the five-grade Likert scale (strongly agree, agree, neutral, disagree, strongly disagree). From the total number of 450 respondents, 180 $(40 \%)$ are already working in a field of education where they can apply knowledge from the taught courses. 237 (52.7\%) of respondents are planning to work in such fields; 90 (20\%) respondents do not know where they want to work and 123 $(27.3 \%)$ respondents are planning to work in a completely unrelated field of education. The structure of respondents is shown in Table 1.

\begin{tabular}{|c|c|c|c|c|c|}
\hline Gender & \multicolumn{2}{|c|}{ Men } & \multicolumn{2}{|c|}{ Women } & Total \\
\hline & \multicolumn{2}{|c|}{109 (24.2\%) } & \multicolumn{2}{|c|}{341 (75.8\%) } & $450(100 \%)$ \\
\hline \multirow[t]{2}{*}{ Age category } & \multicolumn{2}{|c|}{$21-23$ years } & $24-26$ years & Over 26 years & Total \\
\hline & \multicolumn{2}{|c|}{$137(30.4 \%)$} & $227(50.4 \%)$ & 86 (19.1\%) & 450 (100\%) \\
\hline \multirow[t]{2}{*}{ Study programme } & \multicolumn{2}{|c|}{ BA } & \multicolumn{2}{|c|}{ EM } & Total \\
\hline & \multicolumn{2}{|c|}{$290(64.4 \%)$} & \multicolumn{2}{|c|}{$160(35.6 \%)$} & $450(100 \%)$ \\
\hline \multirow[t]{2}{*}{ Lecture attendance* } & $25 \%$ & $50 \%$ & $75 \%$ & $100 \%$ & Total \\
\hline & $144(32 \%)$ & 58 (12.9\%) & $97(21.6 \%)$ & $151(33.6 \%)$ & $450(100 \%)$ \\
\hline
\end{tabular}

Note: *The decision on whether attendance at lectures would be mandatory or not is made by the course guarantor. Because seminars are always mandatory, attendance at seminars was not examined.

Table 1: Structure of respondents, 2016-2018 (source: own survey)

After clarification of the key dependent and independent variables, we formulated 39 partial null hypotheses assume no relationship between the overall rating of a course and basic identification variables $\left(\mathrm{H}_{0} 1-\mathrm{H}_{0} 5\right)$, partial variables influencing the overall rating of the course summarily called 'course evaluation' $\left(\mathrm{H}_{0} 6-\mathrm{H}_{0} 15\right)$, partial variables influencing positive ratings of the teaching summarily called 'teaching evaluation' $\left(\mathrm{H}_{0} 16-\mathrm{H}_{0} 26\right)$ and partial variables influencing positive ratings of the teacher summarily called 'teacher evaluation' $\left(\mathrm{H}_{0} 27-\right.$ $\mathrm{H}_{0} 39$ ). The variables were ranked by importance depending on the examined strength of the relationship.

The statistical software used to evaluate the data and calculate independence tests (Pearson's chi-square test of independence) was IBM SPSS Statistics 24 . When the obtained $p$-value was below the significance threshold $\alpha=0.05$, the null hypothesis was rejected. The strength of the relationship was examined using the Cramer's $V$ coefficient using the scale given by De
Vaus (2014) as follows: $0.10-0.29$ (low to moderate), 0.30 0.49 (moderate to substantial) and $0.50-0.69$ (substantial to very strong).

\section{RESULTS}

Firstly, we tested the impact of basic identification variables on the overall rating of a course, then we paid attention to variables connected with course evaluation, teaching evaluation and teacher evaluation that also might influence on the overall rating of a course.

\section{Impact of basic identification variables on the overall rating of a course}

Pearson's chi-square test of independence showed that there is a relationship between the overall rating of a course, i.e. whether the course meets students' expectations, and their age $\left(\mathrm{H}_{0} 3: p=0.000, V=0.185\right)$, their employment in the field of 
education $\left(\mathrm{H}_{0} 4: p=0.001, V=0.208\right)$ and regular participation at lectures $\left(\mathrm{H}_{0} 5: p=0.000, V=0.233\right)$. It was also examined that the variables of the study programme $\left(\mathrm{H}_{0} 1\right)$ and gender $\left(\mathrm{H}_{0} 2\right)$ have no impact on the overall rating. Based on the above, $\mathrm{H}_{0} 1$ and $\mathrm{H}_{0} 2$ were not rejected on the level of significance threshold $\alpha=0.05$.
Hypotheses $\mathrm{H}_{0} 3-\mathrm{H}_{0} 5$ were rejected because there is a relationship between the overall rating of a course and age, employment in the field of education and attendance at lectures. The results are shown in Table 2.

\begin{tabular}{llr|rcc} 
No. & Variable & $p$-value & Cramer's $V$ & Strength of relationship \\
\hline $\mathrm{H}_{0} 1$ & Study programme & 0.961 & - & - \\
\hline $\mathrm{H}_{0} 2$ & Gender & 0.481 & - & - \\
\hline $\mathrm{H}_{0} 3$ & Age & 0.000 & 0.185 & Low \\
\hline $\mathrm{H}_{0} 4$ & Employment in the field of education & 0.001 & 0.208 & Low \\
\hline $\mathrm{H}_{0} 5$ & Attendance at lectures & 0.000 & 0.233 & Low \\
\hline
\end{tabular}

Table 2: Basic identification variables, 2016-2018 (source: own survey)

Generally speaking, with increasing age of students tend to give their courses better ratings and feel that their expectations are being fulfilled. Similarly, courses are rated better by students working in a field of education where they can apply the knowledge from the course and who regularly attend lectures. While only $36.1 \%$ of students whose attendance at lectures was below $25 \%$ gave the corresponding course a positive rating, students who attended regularly gave positive answers in $74.8 \%$ of cases. The results show that students who attend lectures regularly give the course a better rating.

\section{Impact of partial variables summarily called 'course evaluation' on the overall rating of the course}

We also examined a relationship between 10 partial variables summarily called 'course evaluation' and the overall rating of the course (i.e. whether the course meets students' expectations).

The results are shown in Table 3 .

\begin{tabular}{lll|ccc} 
No. & \multicolumn{1}{c|}{ Variable } & $p$-value & Cramer's $V$ & Strength of relationship \\
\hline $\mathrm{H}_{0} 6$ & Course is beneficial & 0.000 & 0.468 & Substantial \\
\hline $\mathrm{H}_{0} 7$ & Course is interesting & 0.000 & 0.439 & Substantial \\
\hline $\mathrm{H}_{0} 8$ & Course is important for practice & 0.000 & 0.346 & Moderate \\
\hline $\mathrm{H}_{0} 9$ & Course is difficult & 0.428 & - & Low \\
\hline $\mathrm{H}_{0} 10$ & Course is provided within study materials & 0.000 & 0.250 & Moderate \\
\hline $\mathrm{H}_{0} 11$ & Study materials are adequate & 0.000 & 0.285 & Moderate \\
\hline $\mathrm{H}_{0} 12$ & Course is well integrated with the study programme & 0.000 & 0.352 & Moderate \\
\hline $\mathrm{H}_{0} 13$ & Credit requirements are adequate & 0.000 & 0.285 & Low \\
\hline $\mathrm{H}_{0} 14$ & Examination requirements are adequate & 0.000 & 0.254 & -
\end{tabular}

\section{Table 3: Partial variables summarily called 'course evaluation', 2016-2018 (source: own survey)}

Based on the above, $\mathrm{H}_{0} 9$ and $\mathrm{H}_{0} 15$ were not rejected on the level of significance threshold $\alpha=0.05$. Hypotheses $\mathrm{H}_{0} 6-\mathrm{H}_{0} 8$ and $\mathrm{H}_{0} 10$ $\mathrm{H}_{0} 14$ were rejected because there is a relationship between the overall rating of a course and the partial variables summarily called 'course evaluation'. Based on the examined strengths of the relationships, it can be summarised that students generally give a course a better rating if they consider it beneficial, interesting, well integrated within the study programme and important for practice $(V=0.468-0.346)$. Statistically less important were variables that relate to the successful completion of the course, i.e. scope and quality of supporting materials or adequacy of the requirements for the credit/exam. The results also showed an interesting finding - the lack of any relationship between a positive rating of a course and its difficulty level or adequate time allocation. From the above, it can be concluded that students prefer courses that develop their knowledge and skills and prepare them for their future job rather than courses that are easy to pass. For this reason, students give positive ratings also to courses that are very difficult or require more additional self-study.

\section{Impact of partial variables summarily called 'teaching evaluation' on the overall rating of a course}

Based on the examined relationship between the overall positive rating of a course and agreement (strongly agree, agree, 
neutral, disagree, strongly disagree) with verbal claims concerning teaching evaluation provided below, the variables influencing course rating were ranked by importance. These were 11 partial variables summarily called 'teaching evaluation'. The course meets students' expectations particularly when they are satisfied with the content of seminars and how they are conducted if they consider the lectures easy to understand and logically structured and find the method of teaching appropriate. These variables can be considered substantial because the strength of the relationship as expressed by Cramer's $V$ coefficient was between 0.456 and 0.419 . Students also give more positive ratings to courses in which they are satisfied with how the lectures are conducted if the teacher is helpful and stimulates learning if the seminars complement lectures well, there are a clearly defined objective and course requirements or if they are satisfied with the pace of the teaching $(V=0.399-0.323)$. A particularly surprising result was obtained for the variable 'external experts are involved'. Even though the students give very positive ratings to courses that are applicable in practice, there was only a weak relationship between the overall rating of a course and the involvement of external experts $(V=0.220)$. The results are shown in Table 4.

\begin{tabular}{lll|cc} 
No. & \multicolumn{1}{c|}{ Variable } & $p$-value & Cramer's $V$ & Strength of relationship \\
\hline $\mathrm{H}_{0} 16$ & Course objective and requirements are clearly defined & 0.000 & 0.378 & Moderate \\
\hline $\mathrm{H}_{0} 17$ & Lectures are well conducted & 0.000 & 0.399 & Moderate \\
\hline $\mathrm{H}_{0} 18$ & Lectures are easy to understand & 0.000 & 0.442 & Substantial \\
\hline $\mathrm{H}_{0} 19$ & Lectures are logically structured & 0.000 & 0.436 & Substantial \\
\hline $\mathrm{H}_{0} 20$ & Pace of the teaching is satisfactory & 0.000 & 0.323 & Moderate \\
\hline $\mathrm{H}_{0} 21$ & Appropriate method of teaching the lectures & 0.000 & 0.419 & Substantial \\
\hline $\mathrm{H}_{0} 22$ & External experts are involved & 0.000 & 0.220 & Low \\
\hline $\mathrm{H}_{0} 23$ & Seminars adequately complement the lectures & 0.000 & 0.386 & Moderate \\
\hline $\mathrm{H}_{0} 24$ & Seminar content is satisfactory & 0.000 & 0.456 & Substantial \\
\hline $\mathrm{H}_{0} 25$ & Appropriate method of teaching the seminars & 0.000 & 0.443 & Substantial \\
\hline $\mathrm{H}_{0} 26$ & Teacher is helpful and stimulates learning & 0.000 & 0.396 & Moderate \\
\hline
\end{tabular}

Table 4: Partial variables summarily called 'teaching evaluation', 2016-2018 (source: own survey)

Based on the above, the hypotheses $\mathrm{H}_{0} 16-\mathrm{H}_{0} 26$ were rejected because there is a relationship between the overall rating of a course and the partial variables summarily called 'teaching evaluation'.

\section{Impact of partial variables summarily called 'teacher evaluation' on the overall rating of a course}

As the last step, we examined the relationship between 13 partial variables summarily called 'teacher evaluation' and the overall rating of a course. Based on the obtained results, we can summarise that the overall positive perception of a taught course more strongly depends on the evaluation of the teaching (see Table 4) than the rating of the teacher, even though there were still some relationships. When assessing teachers, the factors that students consider the most important are the ability to present the content and practice it and the ability to capture students' attention and stimulate learning ( $V=0.423-0.394)$. It's also important for students to have teachers who are able to connect the taught content to practice $(V=0.354)$ and evaluate students objectively $(V=0.331)$ than whether they act in a professional manner $(V=$ $0.286)$ and whether their behaviour towards students is proper $(V$ $=0.264$ ). The detailed results are shown in Table 5 .

Based on the above, the hypotheses $\mathrm{H}_{0} 27-\mathrm{H}_{0} 39$ were rejected because there is a relationship between the overall rating of a course and the partial variables summarily called 'teacher evaluation'.

\section{DISCUSSION}

Because the community of a higher education institution consists of both students and teachers, the interaction between these two groups seems to be an essential factor for the modification of education as a step for its development (Nada and Hamed, 2018). Research by Adnot et al. (2017) proved that when low-performing teachers are replaced by more efficient colleagues, the positive impact on study performance of students may be very significant. Every higher education institution whose main objective is to provide services of high quality should, therefore, be interested in the efficiency of its teaching staff, differentiate between exceptional and average teachers and systematically examine how they are perceived by the students (who are the higher education institutions' customers).

Our research examined that students place the greatest emphasis on the benefits of the taught course and give positive ratings even to courses that are very difficult and require more work in preparation. This is confirmed by Rafaila and Duta (2015) who claim that students are willing to self-study and devote maximum effort to learning when the course and taught content contribute to their professional and personal development.

Based on the obtained data, we can formulate the following recommendations for teachers who are preparing the educational courses, teachers who are interested in improving the students' interest in existing courses and for higher 


\begin{tabular}{lll|cc} 
No. & \multicolumn{1}{c|}{ Variable } & $p$-value & Cramer'V & Strength of relationship \\
\hline $\mathrm{H}_{0} 27$ & Teacher acts in a professional manner & 0.000 & 0.286 & Moderate \\
\hline $\mathrm{H}_{0} 28$ & Teacher uses modern teaching techniques & 0.000 & 0.293 & Moderate \\
\hline $\mathrm{H}_{0} 29$ & Teacher uses modern technologies & 0.000 & 0.286 & Moderate \\
\hline $\mathrm{H}_{0} 30$ & Teacher stimulates learning & 0.000 & 0.394 & Moderate \\
\hline $\mathrm{H}_{0} 31$ & Teacher has the ability to capture student's attention & 0.000 & 0.397 & Moderate \\
\hline $\mathrm{H}_{0} 32$ & Teacher visualizes the presented information & 0.000 & 0.340 & Moderate \\
\hline $\mathrm{H}_{0} 33$ & Teacher creates a positive and friendly atmosphere & 0.000 & 0.309 & Moderate \\
\hline $\mathrm{H}_{0} 34$ & Teacher behaves appropriately & 0.000 & 0.264 & Low \\
\hline $\mathrm{H}_{0} 35$ & Teacher has the ability to present the content & 0.000 & 0.423 & Substantial \\
\hline $\mathrm{H}_{0} 36$ & Teacher has the ability to connect the taught content to practice & 0.000 & 0.354 & Moderate \\
\hline $\mathrm{H}_{0} 37$ & Teacher adequately practises the subject matter & 0.000 & 0.404 & Substantial \\
\hline $\mathrm{H}_{0} 38$ & Teacher is dedicated to students & 0.000 & 0.309 & Moderate \\
\hline $\mathrm{H}_{0} 39$ & Teacher evaluates objectively & 0.000 & 0.331 & Moderate \\
\hline
\end{tabular}

Table 5: Partial variables summarily called 'teacher evaluation', 2016-2018 (source: own survey)

education institutions aiming to evaluate the quality of teaching and develop a methodology for teaching quality:

- Regularly evaluate the quality of teaching and the efficiency of teachers. Keane (2015) says that institutions typically carry out quantitative surveys among students who are able to rate their own experience with the teaching. He however also points out that these surveys have issues with validity and readability and recommends applying for peer review.

- When preparing a course, pay particular attention to the logical structure of the lectures and seminars to ensure that knowledge and experience are provided in a clear and easy to understand manner.

- Explain the subject matter carefully and patiently, verify that it was understood and assign exercises focused on past content. The research results of Alauddin and Kifle (2014) coincide with our findings that good course organisation, clear presentation and explanation are among the most important factors influencing students' satisfaction and learning outcomes.

- Combine theoretical learnings with examples from practice or alternatively let students gain and deepen their knowledge by learning from their own experience. The importance of focusing on the students' personal experience and their ability to apply their knowledge in practice also underline Arsenijević and Maljković (2016).

The main benefits of this paper lie in its general overview of the variables influencing the perception of the quality of taught courses by students. Course evaluation included many variables such as the requirements of the course, benefits for practice, the structure of the lectures and how they are conducted, style and method of teaching, the range of supporting materials and the lecturer's characteristics. This paper may, therefore, be useful for teachers who are preparing a course or for higher education institutions developing a methodology for evaluating the quality of teaching and teachers and for creating and innovating degree programmes for accreditation and re-accreditation needs. The main limitation of the paper is that the quantitative survey was carried out at only one public university. Even though the number of questionnaire respondents was fairly large $(n=450)$, they were all students in the Master's study programme. Subsequent research should, therefore, compare the perspective of students of private and public universities as well as of students in Bachelor's and Master's programmes. Such a comparison could reveal different expectations of students from private and public universities, as well as draw attention to the educational needs that may develop during their studies.

\section{CONCLUSION}

The quality of university education has a major impact on students, teachers and society as a whole, which is why the topic of teaching quality assessment may be considered highly relevant today and crucial for the future competitiveness of every country. Our research showed that the overall rating of a course is more strongly influenced by variables related to the course's concept, content and outcome than the evaluation of the teacher. The perception of a course by students is the most strongly impacted by whether they consider it beneficial (0.468) and interesting ( 0.439$)$, whether it's easy to understand (0.442) and logically structured (0.436) and whether the form of presentation and the content of exercises are appropriate (0.456). In teacher evaluation, the most important skill in our analysis was the ability to explain (0.423) and train (0.404) the course content. It was also examined that students give positive ratings even to courses that are very difficult and require more self-study if they are considered beneficial. In our respondent sample, we found no relationship between course rating and gender or studied programme. On the other hand, there was a weak relationship between the respondents' age, their attendance at lectures of the course and whether they work in a field related to the content of the course.

\section{ACKNOLEDGEMENTS}

This article was supported by the Internal Grant Agency of the Czech University of Life Sciences Prague (CIGA) under the Assessing the quality of instruction in the selected field at the Faculty of Economics and Management of the Czech University of Life Sciences Prague Grant, number 20171001. 


\section{REFERENCES}

Adnot, M., Dee, T., Katz, V. and Wyckoff, J. (2017) 'Teacher Turnover, Teacher Quality, and Student Achievement in DCPS', Educational Evaluation and Policy Analysis, Vol. 39, No. 1, pp. 54-76. http:// dx.doi.org/10.3102/0162373716663646

Alauddin, M. and Kifle, T. (2014) 'Does the student evaluation of teaching instrument really measure instructors' teaching effectiveness? An econometric analysis of students' perceptions in economics courses', Economic Analysis and Policy, Vol. 44, No. 2 , pp. 156-168. https://doi.org/10.1016/j.eap.2014.05.009

Arsenijević, J. and Maljković, M. (2016) 'Teachers' Roles in Relation to the Ownership Structure of a Faculty', Procedia Technology, Vol. 22, pp. 1152-1159. https://doi.org/10.1016/j.protcy.2016.01.162

Bowen, H. R. (ed.) (2018) Investment in Learning - The Individual and Social Value of American Education, New York: Routledge.

Chui, T. B., Ahmad, M. S., Bassim, F. A. and Zaimi, N. A. (2016) 'Evaluation of Service Quality of Private Higher Education Using Service Improvement Matrix', Procedia - Social and Behavioral Sciences, Vol. 224, pp. 132-140. http://dx.doi.org/10.1016/j. sbspro.2016.05.417

Devadoss, S. and Foltz, J. (1996) 'Evaluation of Factors Influencing Student Class Attendance and Performance', American Journal of Agricultural Economics, Vol. 78, No. 3, pp. 499-507. http://dx.doi. org/10.2307/1243268

De Vaus, D. (2014) Surveys in Social Research, Abingdon, Oxon: Routledge.

Dolton, P., Marcenaro, O. D. and Navarro, L. (2003) 'The effective use of student time: a stochastic frontier production function case study', Economics of Education Review, Vol. 22, No. 6, pp. 547560. http://dx.doi.org/10.1016/S0272-7757(03)00027-X

Ďurišová, M., Kucharčíková, A. and Tokarčíková, E. (2015) ‘Assessment of Higher Education Teaching Outcomes (Quality of Higher Education)', Procedia - Social and Behavioral Sciences, Vol. 174, pp. 2497-2502. http://dx.doi.org/10.1016/j.sbspro.2015.01.922

El-Hilali, N., Al-Jaber, S. and Hussein, L. (2015) 'Students' Satisfaction and Achievement and Absorption Capacity in Higher Education', Procedia - Social and Behavioral Sciences, Vol. 177, pp. 420-427. http://dx.doi.org/10.1016/j.sbspro.2015.02.384

Government Regulation no. 274/2016 Coll., on Standards for Accreditation in Higher Education, Prague: Minister of Education, Youth and Sports.

Higher Education Institutions and on Amendments and Supplements to Some Other Acts (the Higher Education Act) No. 111/1998 Coll, Prague: Ministry of the Interior.

Hoang, T. P., Trong, B. Q., Tuan, N. K. and Linh, L. H. (2016) 'Factors Affecting Learners' Satisfaction towards Quality of English Certification Training Services in Vietnam: A Case Study in Ho Minnh City, Vietnam', International Journal of Economics, Commerce and Management, Vol. 4, No. 3, pp. 286-298.

Keane, M. (2015) 'Responsibility for Learning: An Inclusive Approach to Learning and Teaching Evaluation in Higher Education', Procedia - Social and Behavioral Sciences, Vol. 167, pp. 28-37. http://dx.doi.org/10.1016/j.sbspro.2014.12.638

Leeuwenkamp, K. J. G., Brinke, D. J. and Kester, L. (2017) ‘Assessment quality in tertiary education: An integrative literature review' Studies in Educational Evaluation, Vol. 55, pp. 94-116. http:// dx.doi.org/10.1016/j.stueduc.2017.08.001

Lesjak, D. (2018) 'Improving Higher Education (Institutions) with the Matrix of Managerial and Financial Objectives', Procedia -
Social and Behavioral Sciences, Vol. 238, pp. 249-258. https://doi. org/10.1016/j.sbspro.2018.03.030

Lindstadt, M. A. (2005) 'Employing mediation to approach truants', Family Court Review, Vol. 43, No. 2, pp. 303-322. http://dx.doi. org/10.1111/j.1744-1617.2005.00031.x

McCluskey, C. P., Bynum, T. S. and Patchin, J. W. (2004) 'Reducing Chronic Absenteeism: an Assessment of an Early Truancy Initiative', Crime \& Delinquency, Vol. 50, No. 2, pp. 214-234. http://dx.doi.org/10.1177/0011128703258942

Medallon, M. C. and Martinez, G. O. (2014) 'Teaching Effectiveness and Student's Learning Acquisition in Selected Major Courses in the International Tourism and Hospitality Management Program', Asia Pacific Journal of Multidisciplinary Research, Vol. 2, No. 1, pp. 131-138.

Ming, J. S. K. (2010) 'Institutional Factors Influencing Students' College Choice Decision in Malaysia: A Conceptual Framework', International Journal of Business and Social Science, Vol. 1, No. 3 , pp. 53-58.

Ministry of Education, Youth and Sports (2015) Higher Education Development Framework for 2020, [Online], Available: http:// www.vzdelavani2020.cz/images obsah/dokumenty/ramec vs.pdf [11 Jul 2018]

Nada, S. and Hamed, M. (2018) 'Students Feedback for Faculty Education Development in Developing Countries: An Egyptian Sample', International Journal of Education and Information Technology, Vol. 3, No. 3, pp. 31-45.

Orindaru, A. (2015) 'Changing Perspectives on Students in Higher Education', Procedia Economics and Finance, Vol. 27, pp. 682691. http://dx.doi.org/10.1016/S2212-5671(15)01049-7

Pawłowski, K. (2009) 'The 'Fourth Generation University' as a Creator of the Local and Regional Development', Higher Education in Europe, Vol. 34, No. 1, pp. 51-64. https://doi. org $/ 10.1080 / 03797720902747017$

Pereira, C. A, Araujo, J. F. E. A. and Machado-Taylor, M. L. (2018) "The Brazilian higher education evaluation model: "SINAES" sui generis?', International Journal of Educational Development, Vol. 61, pp. 5-15. http://dx.doi.org/10.1016/j.ijedudev.2017.11.007

Prisacariu, A. (2015) 'New Perspectives of Quality Assurance in European Higher Education', Procedia - Social and Behavioral Sciences, Vol. 180, pp. 119-126. http://dx.doi.org/10.1016/j. sbspro.2015.02.094

Rafaila, E. and Duta, N. (2015) 'Teaching and Self-teaching in Higher Education', Procedia - Social and Behavioral Sciences, Vol. 197, pp. 1230-1235. http://dx.doi.org/10.1016/j.sbspro.2015.07.384

Scott, P., Gallacher, J. and Parry, G. (2017) New languages and landscapes of higher education, Oxford, United Kingdom: Oxford University Press.

Stanca, L. (2006) 'The Effects of Attendance on Academic Performance: Panel Data Evidence for Introductory Microeconomics', The Journal of Economic Education, Vol. 37, No. 3, pp. 251-266. http://dx.doi.org/10.3200/JECE.37.3.251-266

Stronge, J. H. (2018) Qualities of effective teachers, Alexandria, Virginia: ASCD.

Wiese, M., Van Heerden, C. H. and Jordaan, Y. (2010) 'The role of demographics in students' selection of higher education institution', ACTA Commercii - Independent research journal in the management sciences, Vol. 10, No. 1, pp. 150-163. http:// dx.doi.org/10.4102/ac.v10i1.124 